\title{
Psychopathology and parent-child relationships in illicit drugs users
}

\section{DOI: http://doi.org/10.26758/8.1.6}

Nina Erjavec (1) and Gregor Žvelc (2)

(1) University Medical Centre Ljubljana, SLOVENIA

(2) University of Ljubljana, Faculty of Arts, Department of Psychology, SLOVENIA

Address correspondence to: Nina Erjavec, University Medical Centre Ljubljana, The Division of Internal Medicine, Zaloška cesta 7, 1000 Ljubljana, Slovenia. Ph: 00386-40-565-085; E-mail: erjavec.na@gmail.com

\begin{abstract}
Objectives: Drug usage represents an important and profound problem, as it can have long-term negative effects on the individual and society. According to previous studies, drug usage is connected to several factors, amongst which we also find psychopathology and the parent-child relationship. The purpose of this study was to explore illicit drug use, as well as to investigate its potential connections to psychopathology and the parent-child relationship of the subject.

Material and methods: There were 475 participants included in the research, all of them young adults from Slovenia. The Drug Usage Questionnaire was used for the drug use assessment, Symptom Checklist-90-Revised was used to assess the psychopathology symptoms, and the Parental Bonding Instrument was used for the assessment of parent-child relationships. The results were gathered in the summer of 2015.

Results: Most participants from the sample have tried marijuana, and the lowest amount have tried heroin. The number of drugs tried and the frequency of drug use is higher for men than for women. A significantly larger percentage of males have tried one or more illicit substances at least once. Drug usage is positively correlated to psychopathology, although correlations are small. Mother and father care are negatively correlated to drug usage, and only a mother's overprotection is positively correlated to the researched variable.

Conclusions: The correlations between variables are small, but statistically significant, which indicates that drug usage is a wide and complex phenomenon. The research has demonstrated that drug use significantly correlates with psychopathology, parental care, and a mother's overprotection. These factors can be considered when designing preventative and therapeutic programs. The research indicated a need for further research in this field.
\end{abstract}

Keywords: drug usage; psychopathology; comorbidity; parent-child relations.

\section{Introduction}

Regular substance use represents an important and profound problem in today's society, as it has short- and long-term consequences for an individual and society. Drug usage can negatively affect mental and physical well-being, criminal behavior, educational achievement, independence, autonomy, and the development of intimate relationships (Newcomb and Bentler, 1988). 
Drug users vary in their drug use patterns, types of used drug, the effect of drugs on their functioning, general personal adaptability, and the presence of personal or family problems. Drug use is not a uni-dimensional problem and is manifested in a wide spectrum of problems. The definition and classification of drug use is a complex challenge (Carr, 2006).

\section{The question of causality}

Most researchers agree that there are complex mechanisms present, not simple linear functions, and that those mechanisms are not sufficiently explored (Demetrovics, 2009). There is an ongoing debate among professionals about the timeline of the emergence of drug use and psychopathology. There are four hypotheses regarding the timeline: 1) drug use can be interpreted as a symptom of some other psychiatric disorder; 2) drug use is developed as a coping mechanism for a psychiatric disorder (self-medication); 3) a psychiatric disorder is developed as a consequence of drug use; and 4) both drug use and psychiatric disorder are parallel processes and emerge from shared etiological factors (Strakowski and DelBello, 2000; Verheul, 2001). However, these four explanations of relations between drug use and psychopathology are not the only ones possible. It is also likely that one disorder develops first, increases risk factors, and contributes to the development of a second disorder (Demetrovics, 2009). None of the models can explain the phenomenon of comorbidity by itself. In some cases, the connections between one substance and a mental disorder can be better explained by one model, and in the case of a different substance and disorder, a different model is more appropriate (Demetrovics, 2009). Several variables are involved in drug use, both hard and soft drugs. For example, alcohol consumption tends to be quite high especially among men, in peer groups, in the case of those who have problems to socialize and correlates with some accentuated personality traits: Demonstrativeness, Hyper-perseverance, Uncontrollability, Hyperthymia, Cyclothymia, Exaltation (Rada and Ispas, 2016).

\section{Comorbidity of drug usage and psychiatric disorders}

The combination of psychoactive substance use and mental disorder leads to worsened prognosis both in youth and adults, so the problem of comorbidity is often researched in drug use/abuse studies (Demetrovics, 2009).

Comorbidity of substance use and other psychiatric disorders is pretty common, as seen in a lot of studies. Lai and Sitharthan (2012) found a significant correlation between drug use and psychopathology, both general psychopathology and the six most common disorders (anxiety, bipolar affective disorder, major depression, personality disorders, severe stress, and schizophrenia). Lev-Ran, Le Foll, McKenzie, and Rehm (2008) found that persons with mental disorders are 10 times more likely to use marijuana than persons without mental disorders, and that prevalence of marijuana use gets higher with the number of psychiatric diagnoses. They found that $79 \%$ of all people with lifelong psychiatric disorders have a comorbid disorder. High prevalence of psychiatric comorbidity (67.1\%) was also observed in young heroin users (Rodriguez-Llera et al., 2006). The most frequent comorbid disorders in heroin users are anti-social personality disorder (32.9\%), borderline personality disorder (22.1\%), and major depressive disorder (17.4\%). Sareen et al. (2006) found significant connections between anxiety disorders and cocaine, stimulants, hallucinogens, and heroin use. Comorbidity was the highest for panic disorder and hallucinogens use. The use of these drugs also correlates with specific phobias, agoraphobia, generalized anxiety disorder and posttraumatic stress disorder. A total of $20.1 \%$ of the patients diagnosed with bipolar disorder and $10.9 \%$ of patients diagnosed with depressive disorder also have comorbid substance use disorder (Nesvag, 2015). Horwood et al. (2012) found an important linear connection between the frequency 
of marijuana use and the severity of depressive symptoms. Higher marijuana use is connected with a higher severity of depressive symptoms. Ringen et al. (2008a) compared the severity of drug use in patients during the remission phase of a psychotic disorder with the general population sample and found that life-long drug use is significantly higher in psychotic patients than in the general population. This is typical for all drugs, but the biggest difference was found in lifelong amphetamine and cocaine use. Ringen et al. (2008b) found a significant positive connection between the amount of illicit drugs taken at the moment and the severity of psychiatric symptoms in schizophrenia.

As we can see, illicit drug usage is correlated with different psychiatric disorders and comorbidity of substance use disorders, and other psychiatric disorders are pretty common.

\section{Parental bonding and substance use}

Parker et al. (1979) identified four types of parenting that differ by parental overprotection and care. The dimension of care relates to parental warmth against coldness and rejection. The dimension of overprotection describes psychological control against psychological autonomy. Optimal parenting (high care, low overprotection) is a protective factor against substance use (Jurcik, Moulding and Naujokaitis, 2013).

Research shows that extremely overprotective and un-supportive, and also not well-defined parenting full of conflicts are connected to substance use and abuse in young people (Rhodes et al., 2003). Kandel, Kessler, and Margulies (1978) found an important connection between the lack of closeness with parents and a higher probability of substance use. In contrast, a positive family life with an open, trusting, and caring relationship with parents is a factor that protects or delays experimenting with illicit drugs and problematic substance use (Stoker and Swadi, 1990). King and Chassin (2004) showed that parental support is correlated with up to $50 \%$ less risk for the development of substance abuse.

\section{Research problem and hypothesis}

This study aims to explore the connections between three well-studied but not entirely understood psychological phenomenon: substance use/abuse, psychopathology, and parental bonding on a Slovenian sample.

We predict that general and specific substance abuse will correlate positively with different psychopathological symptoms. Furthermore, we predict that parental care will correlate negatively with substance use, whereas parental overprotection will correlate positively.

\section{Material and methods}

\section{Participants}

The study was applied via e-questionnaire and participants from the general public were randomly invited via social media by exposure to researcher's posts about the study, via web portal DrogArt, and via e-mail to members of Society of psychology students at the University of Ljubljana. The invitation clearly stated the aim of the study and that everybody of age 18 to 35 can participate. Data were collected during the summer of 2015.

The total of participants was 475 people, with 137 (28.8\%) males and 337 females $(71.2 \%)$. Age range: $12.5 \%$ aged from 18 to $20,60.1 \% 20$ to $25,18.1 \% 25$ to 30 , and $9.3 \% 30$ to 35 . 


\section{Instruments}

Substance Use Questionnaire: For the needs of this study, DrogArt's Mefedron Use Questionaire was adapted. Participants answered questions about drug use: whether or not they use illicit substances, which substance they use (options: marijuana/hashish, cocaine, heroin/other opioid, natural hallucinogens, synthetic hallucinogens, ecstasy, and amphetamines). They also had an option to write other drugs they use which were not on the list. Next, they had to check how often the drug is used.

Symptom Checklist-90-Revised: As a measure of psychopathology, Symptom Checklist90-Revised by Derogatis (1992; Pearson Clinical, 2017) was used. The test is composed of 90 items that are distributed over nine scales (somatization, obsessive-compulsive, interpersonal sensitivity, depression, anxiety, hostility, phobic anxiety, paranoid ideation, and psychoticism).The test also measures the global indicator of distress with the Global Severity Index - GSI (Pearson Clinical, 2017). Participants have to respond to statements about symptoms or general welfare on a scale ranging from 0 (it didn't burden me at all) to 4 (it burdened me a lot). Most people need 12 to 15 minutes to complete it (Pearson Clinical, 2017). The test can be used for evaluating psychopathology on different populations, from a healthy population to patients with a physical illness or psychiatric patients (Pearson Clinical, 2017). Alfa coefficients in our sample ranged from .8 for phobic anxiety to .92 for depression.

Parental Bonding Instrument: The authors of the questionnaire are Parker, Tupling, and Brown (1979). It was translated into Slovenian by Maša and Gregor Žvelc (M. Žvelc, 2006). The Parental Bonding Instrument is a self-assessment questionnaire measuring parental bonding in the first 16 years of life. It consists of 25 items which are completed separately for the relationship with the mother and for the relationship with the father. It measures the basic dimensions of parenting: parental care and parental overprotection. Parental care refers to a loving relationship, warmth, support, and interest in the child. In contrast to the care dimension are rejection and indifference. The dimension of parental overprotection refers to tying the child to oneself, encouraging dependency, overprotection, and having too much control over the child. The opposite is described by encouraging autonomy and independence (Parker, 1979). The alpha coefficients in our sample were .92 for maternal care, .95 for paternal care, .91 for maternal overprotection, and .88 for paternal overprotection.

\section{Procedure}

Participants first answered demographic questions about gender, age, and the questions about substance use. Then, they completed Symptom Checklist-90-revised and the Parental Bonding Instrument.

The collected data was first processed in Excel, and then in SPSS. The reliability of the entire test battery was very high, but the data was not distributed normally, so non-parametric statistical tests had to be used.

\section{Results}

Table 1 shows data regarding general drug use. We can see that the majority of the participants have tried marijuana, but that the usage of other drugs is a lot lower. By its use, ecstasy is next, and then amphetamines, natural hallucinogens, cocaine, synthetic hallucinogens, and other drugs. Heroin was used by the fewest people in the sample. Concerning specific drugs, heroin use is 
the only one where there are no differences between genders. Other drugs have been tried by a significantly higher percentage of men than women.

Table 1. Number, percent of participants, and gender differences regarding usage of listed drug at some point in a participant's life

\begin{tabular}{|l|c|c|c|c|c|c|}
\hline & $\mathrm{N}(\%)$ & Gender & $\%$ & Df & $H^{2}$ & $p$ \\
\hline Marijuana & $384(80.8)$ & $\mathrm{M}$ & 91 & 1 & 11.367 & .001 \\
\hline Cocaine & & $\mathrm{F}$ & 77 & & & \\
\hline & $139(29.3)$ & $\mathrm{M}$ & 47 & 1 & 25.541 & .000 \\
\hline Heroine & $25(5.3)$ & $\mathrm{M}$ & 8 & 1 & 2.873 & .112 \\
\hline & & $\mathrm{F}$ & 4 & & & \\
\hline Natural hallucinogens & $144(30.3)$ & $\mathrm{M}$ & 47 & 1 & 24.049 & .000 \\
\hline & & $\mathrm{F}$ & 24 & & & \\
\hline Synthetic hallucinogens & $75(15.8)$ & $\mathrm{M}$ & 26 & 1 & 13.497 & .000 \\
\hline & & $\mathrm{F}$ & 12 & & & \\
\hline Ecstasy & $177(37.3)$ & $\mathrm{M}$ & 52 & 1 & 15.338 & .000 \\
\hline & & $\mathrm{F}$ & 32 & & & \\
\hline Amphetamine & $158(33.3)$ & $\mathrm{M}$ & 50 & 1 & 20.772 & .000 \\
\hline & & $\mathrm{F}$ & 28 & & & \\
\hline Other drugs & $45(9,5)$ & $\mathrm{M}$ & 13 & 1 & 2.99 & .118 \\
\hline & & $\mathrm{F}$ & 8 & & & \\
\hline
\end{tabular}

Table 2. Frequency of general drug use

\begin{tabular}{|l|r|r|}
\hline & $N$ & \multicolumn{1}{|c|}{$\%$} \\
\hline Never & 96 & 20.2 \\
\hline I stopped using it & 85 & 17.9 \\
\hline Less than once a year & 29 & 6.1 \\
\hline Once a year & 20 & 4.2 \\
\hline A couple of times a year & 87 & 18.3 \\
\hline Once a month & 22 & 4.6 \\
\hline 2-3 times a month & 32 & 6.7 \\
\hline Once a week & 19 & 4.0 \\
\hline A couple of times a week & 47 & 9.9 \\
\hline Daily & 17 & 3.6 \\
\hline A couple of times a day & 21 & 4.4 \\
\hline
\end{tabular}


Table 2 shows the frequency of general drug use. One-fifth of the sample has never tried drugs, but a very similar percentage of the sample has stopped their drug abuse and uses drugs a couple of times a year. There are some differences concerning gender. There are $91 \%$ of at least one-time drug users among men, and 77\% among women $(\mathrm{H} 2=12,558 ; \mathrm{df}=1 ; \mathrm{p}<.001 ; \mathrm{w}=.17 ; 1$ $\beta=.95)$.

The frequency of general drug use is significantly correlated to some psychopathological symptoms (Table 3). The correlations with obsessive-compulsive symptoms, anxiety, phobic anxiety, paranoid ideation, psychoticism, and the Global Severity Index are low but statistically significant. The correlation with obsessive-compulsive symptoms is the highest, and the correlation with psychoticism follows. Table 3 shows that the use of different substances correlates with different psychopathological symptoms in a similar fashion as the frequency of general drug use. The frequency of amphetamine use correlates with most psychopathology symptoms, and the correlations are the highest. However, we have to interpret the results carefully, because it seems that the use of heroin does not correlate with psychopathology. When we look at the sample, we see that there are so few heroin users that we cannot draw conclusions from these results regarding heroin use. The frequency of use of all drugs (except heroin) correlates with obsessive-compulsive symptoms, and most are correlated to psychotic symptoms.

Table 3. Correlations between the frequency of substance use and psychopathology scales on Symptom Checklist-90-Revised

\begin{tabular}{|l|r|r|r|r|r|r|r|r|}
\hline & $\begin{array}{c}\text { General } \\
\text { substance } \\
\text { use }\end{array}$ & Marijuana & Cocaine & Heroine & $\begin{array}{c}\text { Natural } \\
\text { hallucino- } \\
\text { gens }\end{array}$ & $\begin{array}{c}\text { Synthetic } \\
\text { hallucino- } \\
\text { genes }\end{array}$ & Ecstasy & $\begin{array}{c}\text { Amphe- } \\
\text { tamines }\end{array}$ \\
\hline SOM & .060 & .036 & .066 & -.016 & -.001 & -.025 & .031 & .045 \\
\hline O-C & $.186^{* *}$ & $.164 * *$ & $.140^{* *}$ & .017 & $.113 *$ & $.093 *$ & $.184 * *$ & $.198^{* *}$ \\
\hline I-S & .074 & .062 & .032 & -.018 & .022 & .006 & .079 & $.108^{*}$ \\
\hline DEP & .082 & .069 & .053 & -.003 & .029 & .025 & $.100^{*}$ & $.106^{*}$ \\
\hline ANX & $.109^{*}$ & .090 & $.115^{*}$ & .021 & .046 & 066 & .091 & $.135^{* *}$ \\
\hline HOS & .060 & .041 & .087 & .020 & .018 & .035 & .072 & $.109 *$ \\
\hline PHOB & $.095^{*}$ & .087 & $.115^{*}$ & .039 & $.121 *$ & .085 & $.111^{*}$ & $.126^{* *}$ \\
\hline PAR & $.150^{* *}$ & $.132^{* *}$ & $.140^{* *}$ & .057 & .084 & .053 & $.135^{* *}$ & $.139 * *$ \\
\hline PSY & $.168^{* *}$ & $.153^{* *}$ & $.102^{*}$ & .058 & $.103 *$ & .087 & $.133^{* *}$ & $.141^{* *}$ \\
\hline GSI & $.101^{*}$ & .082 & $.104 *$ & .013 & .062 & .008 & .093 & $.139 * *$ \\
\hline
\end{tabular}

Note. $\mathrm{SOM}=$ somatisation; O-C = obsessive-compulsive; I-S = interpersonal sensitivity; DEP = depression; ANX = anxiety; $\mathrm{HOS}=$ hostility; $\mathrm{PHOB}=$ phobic anxiety; $\mathrm{PAR}=$ paranoid ideation; $\mathrm{PSY}=$ psychoticism; $\mathrm{GSI}=\mathrm{Global}$ Severity Index. $* * p<.01 ; * p<.05$. Spearman's $\rho$.

Table 4 shows correlations between parental bonding and the frequency of drug use. The correlations between general drug use frequency and parental care are negative and statistically significant, but small. This means that participants who had warmer, more caring relationships with parents use drugs less frequently than participants with parents who were rejective and indifferent. Participants with mothers who were warm and caring, use amphetamines, ecstasy, marijuana, and cocaine less frequently. Paternal care correlates negatively to ecstasy, cocaine, amphetamine, and marijuana use frequency. All the correlations are small. 
The correlation between parental overprotection and general drug use frequency is statistically significant only in the case of maternal overprotection and not paternal overprotection (Table 4). This means that participants with mothers who were overprotective, controlling, and encouraged dependency, use drugs more frequently than people with mothers who encouraged autonomy and independence. However, paternal overprotection is not correlated with general drug use frequency. The use of amphetamines, marijuana, cocaine, and ecstasy is more frequent with participants whose mothers were more overprotective and encouraged dependence, than with participants whose mothers encouraged independence. All the correlations are small. Paternal overprotection is positively correlated only with amphetamine and ecstasy use.

Table 4. Correlation between parental bonding and drug use frequency

\begin{tabular}{|l|r|r|r|r|}
\hline & \multicolumn{2}{|c|}{ Parental care } & \multicolumn{2}{c|}{ Parental overprotection } \\
\hline & Mother & Father & \multicolumn{1}{c|}{ Mother } & \multicolumn{1}{c|}{ Father } \\
\hline General drug use & $-.162^{* *}$ & $-.146^{* *}$ & $.178^{* *}$ & .04 \\
\hline Marijuana & $-.147^{* *}$ & $-.131^{* *}$ & $.163^{* *}$ & .03 \\
\hline Cocaine & $-.148^{* *}$ & $-.144^{* *}$ & $.136^{* *}$ & .08 \\
\hline Heroin & -.07 & -.04 & .10 & .06 \\
\hline Natural hallucinogens & -.06 & -.07 & .08 & .01 \\
\hline Synthetic hallucinogens & -.09 & -.04 & .08 & -.01 \\
\hline Ecstasy & $-.175^{* *}$ & $-.172^{* *}$ & $.129 *$ & $.097 *$ \\
\hline Amphetamines & $-.182^{* *}$ & $-.132^{* *}$ & $.176^{* *}$ & $.126^{* *}$ \\
\hline
\end{tabular}

Note. ${ }^{* *} p<.01 ; * p<.05$. Spearman's $\rho$.

\section{Discussions}

Concerning the demographic data, the results showed that drug use varies by gender. A significantly larger percentage of males have tried one or more illicit substances at least once, and significantly more men have tried all of the listed drugs except heroin, where the sample was too small to draw any conclusions. Recent studies show that respecting the values of participants in such scientific research is an essential condition, to the detriment of obtaining some spectacular results (Baciu and Pungă, 2017). These findings are consistent with previous studies showing that men use drugs more frequently than women (Newcomb et al., 2014).

It was expected that drug use would correlate significantly to psychopathology. The results showed small, but significant connections between drug use and psychopathology both in general drug use and use of specific drugs. This is consistent with previous studies, where it was found that psychiatric symptoms are more common in populations with substance use problems than with healthy populations (Lai and Sitharthan, 2012; Lev-Ran, Le Foll, McKenzie, and Rehm, 2008; Rodriguez-Llera et al., 2006; Sareen et al., 2006, etc.). The correlations were small, which can be explained by the sample, which was non-clinical. Demetrovics (2009) found that the prevalence of comorbidity is a lot higher in clinical than non-clinical samples. He also found a connection between drug use and psychotic symptoms, which was confirmed in this study, where a correlation between drug use (general and specific) and psychoticism and paranoid ideation was found. Other studies discovered connections between substance use and anxiety disorders (Sareen et al., 2006), which is consistent with our findings of small correlations between general and specific drug use and 
obsessive-compulsive, anxiety, and phobic anxiety symptoms. Connections between general drug use and specific drug use with depressive symptoms have been found. This is consistent with findings of Neswag et al. (2015), who found high comorbidity of substance use in a sample with bipolar disorder and depression.

The correlations can be explained by different theories. Psychopathology could be a consequence of substance use, as drugs can cause epigenetic changes in the brain, which alter the memory functions, executive functions, cognition, behavior, and lower the worth of natural, nondrug related awards (Madras, 2012). Conversely, drug use can also be a form of self-medication of different psychopathological symptoms (Wurmser, 1974; Khantzian, 1985, 1997). Subclinical substance use and negative emotional symptoms can contribute to the development of each other (Valentiner et al., 2004). The connections can also be explained by shared etiological factors that make psychopathology and substance use parallel processes (Demetrovics, 2009).

Based on the literature, we expected correlations between parental bonding and substance use, and the results partially confirmed our predictions. Higher drug use frequency correlates negatively with parental care. Participants, whose mother and father had a more loving relationship, helped them when needed and expressed interest in them, and used illicit substances less frequently than participants whose parents rejected them. Lack of parental care was positively correlated with the frequency of stimulant and marijuana use. Kandel, Kessler and Margulies (1978) got similar results in their study: unsupportive parenting styles are connected with substance use and abuse of young people. Stoker and Swaldy (1990) marked a caring relationship as a protective factor, which protects from or delays drug use.

Maternal overprotection correlates positively with more frequent drug use, but paternal overprotection has no connection to general drug use. Maternal overprotection is correlated to more frequent use of stimulants and marijuana, paternal overprotection correlates only to use of amphetamines and ecstasy. Correlations between highly overprotective parenting and higher substance use were also found in previous studies (Rhodes, 2003).

The results can be explained by various theories. From a psychodynamic point of view, people with substance use problems often had disturbed early object relations (Woollcott, 1981; Johnson, 1993; Krystall, 1993). Drug use can be seen as compensation for lack of quality interpersonal experience (Žvelc, 2011). By Ackard et al. (2006), a quality child-parent relationship is connected to lower risk for development of a substance use problem. Allen and Land (1999) have found that young people, who have a better relationship with their parents, turn to them for information, and they internalize their advice, most likely even concerning drug use.

\section{Conclusions}

This study includes a rather large sample of young people. We sampled people who don't use drugs, some recreational drug users, and even regular drug users, which helped to highlight the problem of substance abuse among young people in Slovenia. We got some interesting information about the popularity of drug use. Marijuana is by far the most used drug in the sample, and heroin the least. We have discovered differences concerning gender, as men have tried more drugs than women on average. Significant correlations between psychopathology and the frequency of drug use were found. Higher results on psychopathology scales are positively correlated with the frequency of general and specific drug use; the first hypothesis was confirmed. Significant correlations between parental bonding and frequency of drug use were also found. Both maternal and paternal care are negatively correlated with drug use, but only maternal overprotection is positively 
correlated to drug use, so the second hypothesis was partially confirmed. Research findings may be useful for designing preventative and therapeutic programs. It is important to consider comorbidity when dealing with different mental disorders. We need to be cautious about the presence of other mental disorders when working with drug users and about drug use when we are working with other psychiatric illness.

The study had some shortcomings which could be eliminated in future studies. Most are concerned with the sample, which is not representative for the Slovenian population. The results were gathered via web survey on social media, and via a website which is mainly visited by drug users that seek help or information, so the sample is specific. Furthermore, there are a lot more women included than men. Even though the sample is pretty big, the groups of some specific drug users were too small to draw any conclusions. The samples of specific drug users should be bigger in future studies. The frequency of drug use and whether or not a person has used a certain drug was used as a criterion. This may not be the best criterion for drug use, so in future studies, criteria like the amount of consumed substance or simultaneous consumption of various substances could be used. The study should be repeated on a clinical sample of people with substance abuse diagnosis and people with other psychiatric diagnoses, and be compared to a general, non-clinical sample.

\section{References}

1. Ackard, D., Neumark-Sztainer, D., Story, M., and Perry, C., 2006. Parent-Child Connectedness and Behavioral and Emotional Health among Adolescents. American Journal of Preventive Medicine, [online] 30(1), pp.59-66. Available at: National and University Library website, Ljubljana, Slovenia. 〈http://dx.doi.org.nukweb.nuk.uni-lj.si/10.1016/j.amepre.2005.09.013> [Accessed 13 June 2017].

2. Allen, J. and Land, D., 1999. Attachment in adolescence. In: J. Cassidy, P.R. Shaver, eds. Handbook of attachment: Theory, research, and clinical applications. New York, NY, US: Guilford Press. pp.319-335

3. Baciu, A., Pungă, A., 2017. Ethical implications of a quantitative study that analyzes the drug consumers from a Bucharest neighborhood. Romanian Journal of Legal Medicine, 25(1), pp.113-119. DOI: $10.4323 /$ rjlm.2017.113

4. Carr, A., 2006. The Handbook of Child and Adolescent Clinical Psychology: A Contextual Approach, 2nd Edition. New York, NY, US: Routledge/Taylor and Francis Group.

5. Demetrovics, Z., 2009. Co-morbidity of drug addiction: An analysis of epidemiological data and possible etiological models. Addiction Research and Theory, [online] 17(4), pp.420-431. Available at: National and University Library website, Ljubljana, Slovenia. <http://web.b.ebscohost.com.nukweb.nuk.uni-lj.si > [Accessed 4 June 2017].

6. Derogatis, L.R., 2017. Symptom Checklist-90-Revised (SCL-90-R®). Available at: $<$ http://www.pearsonclinical.com/psychology/products/100000645/symptom-checklist-90revised-scl-90-r.html\#tab-details> [Accessed 30 June 2017].

7. Horwood, L., Fergusson, D., Coffey, C., Patton, G., Tait, R., Smart, D., Letcher, P., Silins, E., and Hutchinson, D., 2012. Cannabis and depression: an integrative data analysis of four Australasian cohorts. Drug and Alcohol Dependence, [online] 126(3), pp.369-378. Available at: National and University Library website, Ljubljana, Slovenia. <http://web.b.ebscohost.com.nukweb.nuk.uni-lj.si > [Accessed 28 June 2017].

8. Johnson, B., 1993. A developmental model of addictions, and its relationship to the twelve step program of Alcoholics Anonymous. Journal of Substance Abuse Treatment, 10(1), pp.23-30. 
9. Jurcik, T., Moulding, R. and Naujokaitis, E., 2013. How do drug and alcohol use relate to parental bonding and risk perception in university students? Journal of Substance Use, [online] 18(4), pp.254-261. Available at: National and University Library website, Ljubljana, Slovenia. <http://web.b.ebscohost.com.nukweb.nuk.uni-lj.si > [Accessed 13 June 2017].

10. Kandel, D., Kessler, R. and Margulies, R., 1978. Antecedents of adolescent initiation into stages of drug use: A developmental analysis. Journal of Youth and Adolescence, [online] 7(1), pp.1340. Available at: National and University Library website, Ljubljana, Slovenia. <http://web.b.ebscohost.com.nukweb.nuk.uni-lj.si> [Accessed 28 June 2017].

11. Khantzian, E. J., 1985. The self-medication hypothesis of addictive disorders: focus on heroin and cocaine dependence. The American Journal of Psychiatry, 142(11), pp.1259-1264.

12. Khantzian, E. J., 1997. The self-medication hypothesis of substance use disorders: reconsideration and recent applications. Harvard Review of Psychiatry, 4(5), pp.231-244.

13. King, K., and Chassin, L., 2004. Mediating and moderated effects of adolescent behavioral undercontrol and parenting in the prediction of drug use disorders in emerging adulthood. Psychology of Addictive Behaviors: Journal of The Society of Psychologists in Addictive Behaviors, [online] 18(3), pp.239-249. Available at: National and University Library website, Ljubljana, Slovenia. <http://web.b.ebscohost.com.nukweb.nuk.uni-lj.si> [Accessed 28 June 2017].

14. Krystal, H., 1977. Self-and object-representation in alcoholism and other drug-dependence: implications for therapy. NIDA Research Monograph, 12, pp. 88-100.

15. Lai, H. and Sitharthan, T., 2012. Exploration of the comorbidity of cannabis use disorders and mental health disorders among inpatients presenting to all hospitals in New South Wales, Australia. American Journal of Drug and Alcohol Abuse, [online] 38(6), pp.567-574. Available at: National and University Library website, Ljubljana, Slovenia. <http://web.b.ebscohost.com.nukweb.nuk.uni-lj.si > [Accessed 28 June 2017].

16. Lev-Ran, S., Le Foll, B., McKenzie, K., George, T., and Rehm, J., 2013. Cannabis use and cannabis use disorders among individuals with mental illness. Comprehensive Psychiatry, [online] 54(6), pp.589-598. Available at: National and University Library website, Ljubljana, Slovenia. <http://web.b.ebscohost.com.nukweb.nuk.uni-lj.si> [Accessed 28 June 2017].

17. Madras, B.K., 2012. Unique consequences of addiction, In: H.J. Shaffer, ed. APA addiction syndrome handbook, Vol. 1: Foundations, influences, and expressions of addiction. [online] Washington, DC, US: American Psychological Association. pp. 317-328. Available at: National and University Library website, Ljubljana, Slovenia. <http://dx.doi.org.nukweb.nuk.unilj.si/10.1037/13751-016> [Accessed 30 June 2017].

18. Nesvåg, R., Knudsen, G., Bakken, I., Høye, A., Ystrom, E., Surén, P., Reneflot, A., Stoltenberg, C. and Reichborn-Kjennerud, T., 2015. Substance use disorders in schizophrenia, bipolar disorder, and depressive illness: A registry-based study. Social Psychiatry and Psychiatric Epidemiology, [online] 50(8), pp.1267-1276. Available at: National and University Library website, Ljubljana, Slovenia. <http://dx.doi.org.nukweb.nuk.uni-lj.si/10.1007/s00127-015-10252)> [Accessed 28 June 2017].

19. Newcomb, M. and Bentler, P., 1988. Impact of adolescent drug use and social support on problems of young adults: a longitudinal study. Journal of Abnormal Psychology, [online] 97(1), pp.64-75. Available at: National and University Library website, Ljubljana, Slovenia. <http://dx.doi.org.nukweb.nuk.uni-lj.si/10.1037/0021-843X.97.1.64> [Accessed 4 June 2017].

20. Newcomb, M., Birkett, M., Corliss, H. and Mustanski, B., 2014. Sexual orientation, gender, and racial differences in illicit drug use in a sample of US high school students. American Journal of 
Public Health, [online] 104(2), pp.304-310. Available at: National and University Library website, Ljubljana, Slovenia. $\quad$ http://dx.doi.org.nukweb.nuk.unili.si/10.2105/AJPH.2013.301702 > [Accessed 30 June 2017].

21. Parker, G., Tupling, H. and Brown, L., 1979. A parental bonding instrument. British Journal of Medical Psychology, 52(1), pp.1-10.

22. Rada, C., and Ispas A.T., 2016. Alcohol consumption and accentuated personality traits among young adults in Romania: a cross-sectional study. Substance Abuse Treatment, Prevention, and Policy, $\quad 11: 36 \quad$ DOI: 10.1186/s13011-016-0080-3, Available at :http://www.substanceabusepolicy.com/content/11/1/36 [Accessed 30 June 2017].

23. Rhodes, T., Lilly, R., Fernández, C., Giorgino, E., Kemmesis, U., Ossebaard, H., Lalam, N., Faasen, I. and Spannow, K., 2003. Risk factors associated with drug use: the importance of 'risk environment'. Drugs: Education, Prevention and Policy, [online] 10(4), pp.303-329. Available at: National and University Library website, Ljubljana, Slovenia. <http://web.b.ebscohost.com.nukweb.nuk.uni-lj.si > [Accessed 28 June 2017].

24. Ringen, P., Melle, I., Birkenæs, A., Engh, J., Færden, A., Jónsdóttir, H., Nesvåg, R., Vaskinn, A., Friis, S., Larsen, F., Opjordsmoen, S., Sundet, K. and Andreassen, O., 2008. Illicit drug use in patients with psychotic disorders compared with that in the general population: a crosssectional study. Acta Psychiatrica Scandinavica, [online] 117(2), pp.133-138. Available at: National and University Library website, Ljubljana, Slovenia.

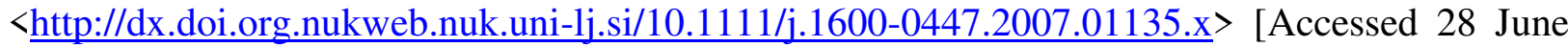
2017].

25. Ringen, P., Melle, I., Birkenaes, A., Engh, J., Faerden, A., Vaskinn, A., Friis, S., Opjordsmoen, S. and Andreassen, O., 2008. The level of illicit drug use is related to symptoms and premorbid functioning in severe mental illness. Acta Psychiatrica Scandinavica, [online] 118(4), pp.297304. Available at: National and University Library website, Ljubljana, Slovenia. <http://web.b.ebscohost.com.nukweb.nuk.uni-lj.si > [Accessed 28 June 2017].

26. Rodríguez-Llera, M., Domingo-Salvany, A., Brugal, M., Silva, T., Sánchez-Niubó, A. and Torrens, M., 2006. Psychiatric comorbidity in young heroin users. Drug and Alcohol Dependence, [online] 84(1), pp.48-55, Available at: National and University Library website, Ljubljana, Slovenia. <http://web.b.ebscohost.com.nukweb.nuk.uni-lj.si> [Accessed 28 June 2017].

27. Sareen, J., Chartier, M., Paulus, M. and Stein, M., 2006. Illicit drug use and anxiety disorders: findings from two community surveys. Psychiatry Research, [online] 142(1), pp.11-17, Available at: National and University Library website, Ljubljana, Slovenia. <http://web.b.ebscohost.com.nukweb.nuk.uni-lj.si > [Accessed 28 June 2017].

28. Stoker, A. and Swadi, H., 1990. Perceived family relationships in drug abusing adolescents. Drug and Alcohol Dependence, 25(3), pp. 293-297.

29. Strakowski, S. and DelBello, M., 2000. The co-occurrence of bipolar and substance use disorders. Clinical Psychology Review, [online] 20(2), pp.191-206, Available at: National and University Library website, Ljubljana, Slovenia. <http://web.b.ebscohost.com.nukweb.nuk.unilj.si> [Accessed 30 June 2017].

30. Valentiner, D., Mounts, N. and Deacon, B., 2004. Panic attacks, depression and anxiety symptoms, and substance use behaviors during late adolescence. Journal of Anxiety Disorders, [online] 18(5), pp.573-585, Available at: National and University Library website, Ljubljana, Slovenia. <http://web.b.ebscohost.com.nukweb.nuk.uni-lj.si > [Accessed 30 June 2017]. 
31. Verheul, R., 2001. Co-morbidity of personality disorders in individuals with substance use disorders. European Psychiatry, [online] 16(5), pp.274-282, Available at: National and University Library website, Ljubljana, Slovenia. <http://web.b.ebscohost.com.nukweb.nuk.unilj.si> [Accessed 30 June 2017].

32. Woollcott, P., 1981. Addiction: Clinical and theoretical considerations. The Annual of Psychoanalysis, 9, pp.189-204.

33. Wurmser, L., 1974. Psychoanalytic considerations of the etiology of compulsive drug use. Journal of the American Psychoanalytic Association, 22(4), pp.820-843.

34. Žvelc, G., 2001. Odvisnost kot poskus samoregulacije (sodobne psihoanalitične teorije odvisnosti). = Addiction as an attempt at self-regulation: Contemporary psychoanalytic theories of addiction. Psihološka Obzorja / Horizons of Psychology, 10(3), pp.57-74.

35. Žvelc, M., 2003. Razvoj slikovnega testa separacije in individualizacije (Development of Pictorial test of Separation and Individuation) Unpublished MsC thesis, University of Ljubljana, Faculty of Arts, Department of Psychology, Slovenia. 